\title{
Insect Vectors (Hemiptera: Cixiidae) and Pathogens Associated with the Disease Syndrome "Basses Richesses" of Sugar Beet in France
}

\author{
Alberto Bressan, Biologie et écologie des phytoplasmes, UMR PME INRA-CNRS-Université de Bourgogne, BP \\ 86510-21065 Dijon cedex, France; Olivier Sémétey, Biologie et écologie des phytoplasmes, UMR PME INRA- \\ CNRS-Université de Bourgogne, BP 86510-21065 Dijon cedex, France; Benoit Nusillard, Entomologie et Lutte \\ Biologique, INRA Antibes, 06560 Valbonne, France; and Denis Clair and Elisabeth Boudon-Padieu, Biologie et \\ écologie des phytoplasmes, UMR PME INRA-CNRS-Université de Bourgogne, BP 86510-21065 Dijon cedex, \\ France
}

\begin{abstract}
Bressan, A., Sémétey, O., Nusillard, B., Clair, D., and Boudon-Padieu, E. 2008. Insect vectors (Hemiptera: Cixiidae) and pathogens associated with the disease syndrome "basses richesses" of sugar beet in France. Plant Dis. 92:113-119.

The syndrome "basses richesses" (SBR) is a disease of sugar beet in eastern France associated with two phloem-restricted, nonculturable plant pathogens: a stolbur phytoplasma and a $\gamma-3$ proteobacterium, here called SBR bacterium. Three planthopper (Hemiptera: Cixiidae) species were found to live near and within sugar beet fields in eastern France: Cixius wagneri, Hyalesthes obsoletus, and Pentastiridius leporinus. The role of these planthoppers in spreading the two pathogens to sugar beet was studied. Based on its abundance and high frequency of infection with the SBR bacterium, $P$. leporinus was considered to be the economic vector of SBR disease. $C$. wagneri, the primary vector of 'Candidatus Phlomobacter fragariae' to strawberry in western France, also was found to be infected by the SBR bacterium and to transmit the pathogen to sugar beet. Neither $C$. wagneri nor $P$. leporinus were infected by stolbur phytoplasma. Populations of $H$. obsoletus living on bindweed (Convolvulus arvensis) and nettle (Urtica dioica) collected near sugar beet fields did not carry the SBR bacterium, but were highly infected with two restriction fragment length polymorphism-differentiable stolbur phytoplasma isolates. In transmission assays, only the bindweed phytoplasma isolate was transmissible to and pathogenic on sugar beet. When compared with controls, the bindweed stolbur phytoplasma and SBR bacterium similarly reduced the biomass of sugar beet plants, but the phytoplasma caused greater reductions in taproot biomass and sugar content than the SBR bacterium.
\end{abstract}

In contrast to the life history of many hemipterous insects, planthoppers in the family Cixiidae (Hemiptera: Fulgoromorpha) live for most of their life cycle as immature stages on roots of host plants. Adults live for only a few weeks, and mated females do not oviposit eggs into plant tissues but, rather, lay them in soil close to host plant roots. In temperate regions, most of these insects are reported as univoltine (i.e., having one generation per year), although often only partial information on their life cycles is available.

In Europe, four planthopper cixiids Hyalesthes obsoletus Signoret, Pentastiridius leporinus (Linnaeus), Reptalus panzeri (Löw, 1883), and $R$. quinquecostatus (Dufour) - have been shown to

Corresponding author: A. Bressan

E-mail: bressan@hawaii.edu

Current address of A. Bressan: Department of Plant and Environmental Protection Sciences, University of Hawaii at Manoa, Honolulu, HI 96822, USA.

Accepted for publication 10 September 2007.

doi:10.1094/PDIS-92-1-0113

(C) 2008 The American Phytopathological Society transmit or to be infected by phytoplasmas, a group of phloem-restricted plantpathogenic bacteria $(8,11,14,17,19,26)$. Thus far, all phytoplasmas vectored by these species are restricted to the stolbur group (16SrXII-A) $(6,16)$, which has been proposed as 'Candidatus Phytoplasma solani' (6). Phytoplasmas within the stolbur group cause yellowing diseases to several cultivated and wild plant species $(4,8,18)$. Recently, different stolbur phytoplasma isolates have been demonstrated to be associated with different planthopper cixiids and host plants $(1,15)$. In particular, Langer and Maixner (15) found that populations of $H$. obsoletus living on nettle (Urtica dioica L.) or bindweed (Convolvulus arvensis L.) were infected consistently by distinct stolbur phytoplasma isolates, designated by the authors as VkI for the nettle isolate and VkII for the bindweed isolate. In the case of grapevine yellows associated with stolbur phytoplasma, different isolates seemed to play different roles in disease epidemics, depending on the geographic area $(1,15,20)$.

In France, Cixius wagneri (China) has been shown to transmit to strawberry a $\gamma-3$ proteobacterium, 'Candidatus Phlomobacter fragariae' $(5,28)$, which is the main pathogen causing the marginal chlorosis disease of strawberry (5). P. leporinus has been demonstrated to be a vector of a bacterium consistently associated with the syndrome "basses richesses" (SBR) of sugar beet $(9,10)$ and thought to be the main pathogen of SBR (24). The former planthopper cixiid first was presumed to be P. beieri (11); however, because of a lack of clear taxonomic characteristics, it was referred to in other previous literature as Pentastiridius sp. (10,23-25). We recently obtained morphological and molecular evidence for its identification as P. leporinus (unpublished). According to their $16 \mathrm{Sr}$ DNA sequences, ' $\mathrm{Ca}$. Phlomobacter fragariae' and the SBR bacterium are closely related $\gamma-3$ proteobacteria within the Arsenophonus clade (25). Diseases caused by these two pathogens have distinctly different geographical distributions, with SBR occurring in eastern France and marginal chlorosis disease of strawberry in western France $(5,24)$.

Insect vectors transmit phytoplasmas in a propagative fashion, with a latent period that ranges from days to weeks $(21,27)$ and persistently retain infectivity, usually for life. Thus far, little is known as to the mechanisms of transmission of the two phloem-restricted $\gamma-3$ proteobacteria. Using transmission electron microscopy, we found the SBR bacterium in internal organs of the vector $P$. leporinus, including midgut and salivary glands (unpublished data). We also obtained evidence for persistence of transmission (9; unpublished data), suggesting that the SBR bacterium might be transmitted, as for phytoplasmas, in a persistent-propagative fashion.

Both stolbur phytoplasma and the SBR bacterium have been detected in diseased sugar beet plants. Furthermore, these phloem-restricted pathogens cause no differentiable symptoms in affected plants in the field. Symptoms include yellowing, leaf proliferation and deformation, necrosis of vascular tissues in tap roots, and reduced sugar content $(10,24)$.

Here, we attempted to clarify the roles of insect species involved with transmission of both stolbur phytoplasma and SBR bacterium to sugar beet in the field. We focused our research on planthopper 
cixiids because they are consistently associated with stolbur phytoplasma and are the only known vectors of ' $\mathrm{Ca}$. Phlomobacter fragariae' and the SBR bacterium. In addition, a large screening of both stolbur phytoplasma and SBR bacteria in 24 hemipterous insects collected from an SBR-affected sugar beet area excluded the presence of the two plant pathogens from insects other than planthopper cixiids (23). We also attempted to clarify the pathogenic role and symptom profiles of each of the two pathogens inoculated separately to sugar beet in transmission assays with the different insect vectors.

\section{MATERIALS AND METHODS}

Insect sampling. To assess the diversity and abundance of cixiid species that feed on sugar beet, sampling was conducted during 2005 and 2006 in two sugar beet fields located in Jura department (FrancheComté Region) during SBR epidemics. Cixiid planthoppers were sampled in fields by using sticky traps made of transparent PVC sheets $(300 \mathrm{~mm}$ long, $210 \mathrm{~mm}$ wide, and $0.2 \mathrm{~mm}$ thick) coated on each side with Soveurode aerosol (Scotts Biosystèmes, France). Traps of a similar type proved efficient for sampling $H$. obsoletus (2). Binder clips fastened the top and bottom of each trap to a 5-mm-diameter, 600mm-long fiberglass stake. Traps were maintained above the vegetation by raising the stakes as the sugar beet plants grew.

During 2005, we selected a rectangular (100 by $260 \mathrm{~m}$ ) sugar beet field that was north-south oriented as the sampling site. Sampling was done on the southern side of the field that was not treated by insecticides. We posted four lines of seven traps placed at a 10-m distance from each other on the line. Lines were parallel to the north-south borders of the field. A line of traps was placed 10,20,40, and 80 m east of the western field border. During 2006, we selected a rectangular (162 by $288 \mathrm{~m}$ ) sugar beet field, also oriented north-south. In order to sample the northern part of the field, we first designed an eight-by-seven grid of contiguous square cells (18 m per side) over the sampling area. Grid sides were parallel or perpendicular to field borders, with east, west, and north sides of the grid being $9 \mathrm{~m}$ from the respective field borders. We posted a total of 72 traps, one at each corner of a square.

In both years, traps were maintained in fields from the beginning of June until just before sugar beet harvesting (late September). This sampling period covered the flight time of most planthopper cixiids in temperate regions according to our previous experience. We counted and removed cixiids from traps every 2 to 3 days during June and July and every week thereafter. Traps in sugar beet fields were changed every 7 to 10 days. We removed insects of uncertain identity with fine forceps and preserved them in $70 \%$ ethanol for later identification based on morphological criteria (12) observed with a dissecting microscope.

Transmission assays. To assess the presence of SBR pathogens in potential vectors and their importance in SBR symptomatology, three species belonging to the family Cixiidae were used for transmission assays: $C$. wagneri, $H$. obsoletus, and $P$. leporinus. Insects were field collected in 2005 and 2006 in the same area as above with a D-Vac (Ventura, CA) aspirator from sugar beet fields, weeds on the borders of sugar beet fields, or in nearby (100- to 400-m distance) fallow fields. We collected separately and kept segregated populations of $H$. obsoletus from bindweed and nettle, referred to hereafter as $H$. obsoletus (b) and $H$. obsoletus (n), respectively. Because nettles in the sugar beet cropping areas in 2006 had low populations of $H$. obsoletus, we used $H$. obsoletus collected on nettles growing near Colmar (Alsace region of France). We transported the collected planthoppers to a glasshouse facility and separated them by species, collecting sites, and date of capture.

For transmission assays, we confined insects on 35- to 50-day-old healthy sugar beet seedlings with cylindrical, meshventilated, PVC cages closed at the bottom with a collar-like sponge pad. We generally confined to each seedling 4 to 5 planthoppers of $C$. wagneri or P. leporinus, 8 to 10 planthoppers of $H$. obsoletus (b), or 20 planthoppers of $H$. obsoletus (n). For each assay, we kept four sugar beet seedlings not exposed to insects as negative controls. We maintained insects on sugar beet seedlings for an inoculation access period of 3 to 4 days. At the end of that period, we collected live and dead insects from caged seedlings and froze them at $-80^{\circ} \mathrm{C}$ for later assay for pathogens in their body. We then sprayed plants with fenitrothion (Chimiberg, Albano S. Alessandro, Italy) at 1.02 $\mathrm{g} /$ liter and kept them in an insect-free glasshouse with natural light and temperature $\left(26 \pm 5^{\circ} \mathrm{C}\right)$ for 4 to 5 months to complete the disease incubation period (time for symptoms to appear).

Pathogen detection and characterization with polymerase chain reaction and restriction fragment length polymorphism analysis. We used a cetyltrimethylammonium bromide procedure to extract DNA from planthoppers and from sugar beet midrib tissue, according to the methods of Gatineau et al. (11) and Daire et al. (4), respectively. Insects collected from the field were checked with polymerase chain reaction (PCR) for the presence of SBR bacterium, ' $\mathrm{Ca}$. Phlomobacter fragariae,' and stolbur phytoplasma. Specimens of $C$. wagneri and $P$. leporinus were tested individually, whereas specimens of $H$. obsoletus (b) and $H$. obsoletus (n) were tested in batches of three. For positive and negative controls, we used DNA samples from known SBR bacterium-infected or nonin- fected $P$. leporinus specimens and known stolbur phytoplasma-infected or noninfected $H$. obsoletus specimens, respectively, and from $C$. wagneri infected by ' $\mathrm{Ca}$. Phlomobacter fragariae' kindly provided by Pascal Salar (INRA Bordeaux). For specific detection of SBR bacterium in insects, we used the Alb1/Oliv1 primer pair designed to amplify the internal transcribed spacer region between $16 \mathrm{Sr}$ and $23 \mathrm{Sr}$ genes of SBR bacterium rRNA operons. PCR products showed a typical fingerprint (23). PCR conditions were according to Sémétey et al. (23). For specific detection of ' $\mathrm{Ca}$. Phlomobacter fragariae' in $C$. wagneri, we used the Pfr1/Pfr4 primer pair to amplify specifically $895 \mathrm{bp}$ of the SpoT gene present in the ' $\mathrm{Ca}$. Phlomobacter fragariae' genome (7). PCR conditions were as those described by Foissac et al. (7). For detection of stolbur phytoplasma in insects, amplification was performed with a direct PCR procedure using primers Stol11f3/Stol11r2 with PCR conditions as described (3).

Insect-exposed sugar beet seedlings were checked with PCR for the presence of SBR bacterium, ' $\mathrm{Ca}$. Phlomobacter fragariae,' and stolbur phytoplasma. Positive controls were DNA samples from stolbur phytoplasma-infected periwinkle (Catharanthus roseus L.) maintained in the greenhouse (StolC isolate from MT Cousin, France), known SBR bacteriuminfected sugar beet, and strawberry infected by ' $\mathrm{C} a$. Phlomobacter fragariae' provided by Pascal Salar. Negative controls were DNA samples from non-insectexposed, healthy seedlings of sugar beet grown in the greenhouse. For the characterization of phloem-restricted proteobacteria in plants, 16SrDNA sequences of SBR bacterium and ' $C a$. Phlomobacter fragariae' (GenBank accession numbers AY057392.1 and AM110766.1, respectively) were aligned using Clustal W software. The reverse primer, rA_PB_2 (5'TCGCCTCTCTCTGTATACG-3'), was manually designed and associated with forward primer Fra5 (28) to obtain a 790-bp amplicon from the 16Sr DNA of both pathogens. Restriction enzyme TaqI was selected using webcutter 2.0 software (http://www.firstmarket.com/cutter/cut2.htm 1). PCR conditions were a predenaturation step at $93^{\circ} \mathrm{C}$ for $3 \mathrm{~min}$, followed by $35 \mathrm{cy}-$ cles at $93^{\circ} \mathrm{C}$ for $1 \mathrm{~min}, 54^{\circ} \mathrm{C}$ for $1 \mathrm{~min}$, and $72^{\circ} \mathrm{C}$ for $1 \mathrm{~min}$. The final extension step was at $72^{\circ} \mathrm{C}$ for $5 \mathrm{~min}$. Amplicons obtained were digested with TaqI. Restriction products were separated in $10 \%$ polyacrylamide gel, stained with ethidium bromide, and visualized under UV light. For the detection of stolbur phytoplasma in sugar beet, we used a nested PCR (3) with Stol11f2/ Stol11r1 as the first pair of primers, then Stol11f3/Stol11r2 as the second pair of primers. PCR conditions were as described (3).

Typing of stolbur phytoplasma isolates was done according to Langer and Maix- 
ner (15). Briefly, DNA from insects and plant samples that were positive for stolbur phytoplasma after PCR with primers Stol11f3/Stol11r2 were amplified with primers ftufAY/rtufAY (22). PCR conditions and restriction fragment length polymorphism (RFLP) analysis with HpaII restriction enzyme were according to Langer and Maixner (15). Fragments were separated by electrophoresis in $10 \%$ polyacrylamide gel, stained with ethidium bromide, and visualized under UV light.

Symptomatology of stolbur phytoplasma and SBR bacterium on sugar beet. The sugar beet seedlings that were inoculated in 2006 in transmission assays with stolbur phytoplasma and SBR bacterium using $H$. obsoletus (b) and $P$. lepori$n u s$ as vectors, respectively, were evaluated for symptom severity. Sugar beet seedlings of the same age and not exposed to insects were used as healthy controls. Parameters that we considered for symptomatology were the entire plant biomass or tap root biomass measured as grams of fresh weight and the refractometric dried substance (RDS) of tap root pulp, which was taken as an estimation of sugar content (13). Measurements were taken 5 months after transmission of pathogens by planthoppers. For plant biomass measurement, sugar beet leaves were removed and the weight of leaves and tap root were recorded separately for each plant. RDS was measured by coarsely grinding $50 \mathrm{~g}$ of tissue of each tap root and centrifuging at low speed $(5 \mathrm{~min}$ at $2,900 \times g)$. The supernatant was filtered through sintered glass and analyzed in a refractometer, which provided the percentage of dry weight expressed in Brix degrees (13). Data obtained on total plant biomass, proportion of tap root biomass to total plant biomass, or RDS values were compared between three treatments (stolbur-affected sugar beet, SBR-affected sugar beet, and healthy sugar beet) with one-way analysis of variance (ANOVA). Before proceeding with ANOVA, data expressed as proportions were arcsine transformed, and data on plant biomass were square-root transformed in order to achieve a normal distribution. Means and 95\% confidence limits of back-transformed data were reported in graphics. Statistics were obtained by using Statistical software (version 6.0; StatSoft, Italy).

\section{RESULTS}

Planthopper cixiid populations. Sticky traps posted in sugar beet fields caught three planthopper cixiids: Cixius wagneri, $H$. obsoletus, and P. leporinus. The most abundant species was $P$. leporinus. Out of a total of 4,033 cixiids caught in 2005 by 28 sticky traps, $97 \%(3,933$ insects $)$ were P. leporinus, $1.9 \%$ (75 insects) were $C$. wagneri, and only $0.6 \%$ (26 insects) were H. obsoletus. During 2006, P. leporinus represented $98.7 \% \quad(9,917$ insects $), \quad C$. wagneri $0.5 \%$ (51 insects), and $\mathrm{H}$. obsoletus $0.8 \%$ (79 insects) of the 10,047 cixiids collected from 72 sticky traps. Temporal patterns and abundance for the three planthopper species caught by sticky traps in 2005 and 2006 are shown in Figure 1. H. obsoletus and P. leporinus had flight activity restricted to the spring and summer. $C$. wagneri occurred not only during spring and summer but also during the late autumn.

Pathogen transmission and detection. PCR detection of SBR bacterium in insects with Alb1/Oliv1 primers produced a typical fingerprint in agarose gel (data not shown) with DNA samples from P. leporinus and $C$. wagneri planthoppers, confirming the presence of the SBR bacterium in specimens of both species, but not in either H. obsoletus (b) or (n) populations (Fig. 2A). We were unable to detect ' $\mathrm{Ca}$. Phlomobacter fragariae' in 69 insects of $C$. wagneri tested with the Pfr1/Pfr4 PCR assay. Specific Stol11 PCR assays for stolbur phytoplasma showed no infection in C. wagneri or P. leporinus planthoppers, whereas both populations of $H$. obsoletus ( $b$ and $n$ ) proved to be highly infected (Fig. 2A). Furthermore, using PCR-RFLP analysis of the tuf gene, we could identify the two stolbur phytoplasma isolates described by Langer and Maixner (15) in $H$. obsoletus populations (b) and (n), respectively (Fig. 3A, lanes 1-3 and 6-10).

Restriction analysis with TaqI of the Fra5/rA_PB_2 amplicon of 16S rDNA enabled us to differentiate the SBR bacterium from ' $\mathrm{Ca}$. Phlomobacter fragariae' in infected plants (Fig. 3B, lanes 1-3). The latter PCR-RFLP method showed that sugar beet seedlings exposed to P. leporinus and $C$. wagneri were infected by SBR bacterium (Fig. 3B, lanes 3-6 and 7-8, respectively) but not by ' $\mathrm{Ca}$. Phlomobacter fragariae' or by stolbur phytoplasma (Fig. 2B). Conversely, seedlings exposed to $H$. obsoletus (b) were infected by stolbur phytoplasma but not SBR bacterium (Fig. 2B). Moreover, only sugar beet seedlings exposed to $H$. obsoletus (b) expressed typical SBR symptoms (Fig. 4) and tested positive for the bindweed isolate of stolbur phytoplasma using PCR-RFLP analysis of tuf gene (Fig. 3A, lanes 4-5). None of the seedlings exposed to $H$. obsoletus (n) expressed any symptoms of SBR (Fig. 2B), and we did not detect stolbur phytoplasma in any of these plants despite several attempts using nested PCR amplification of
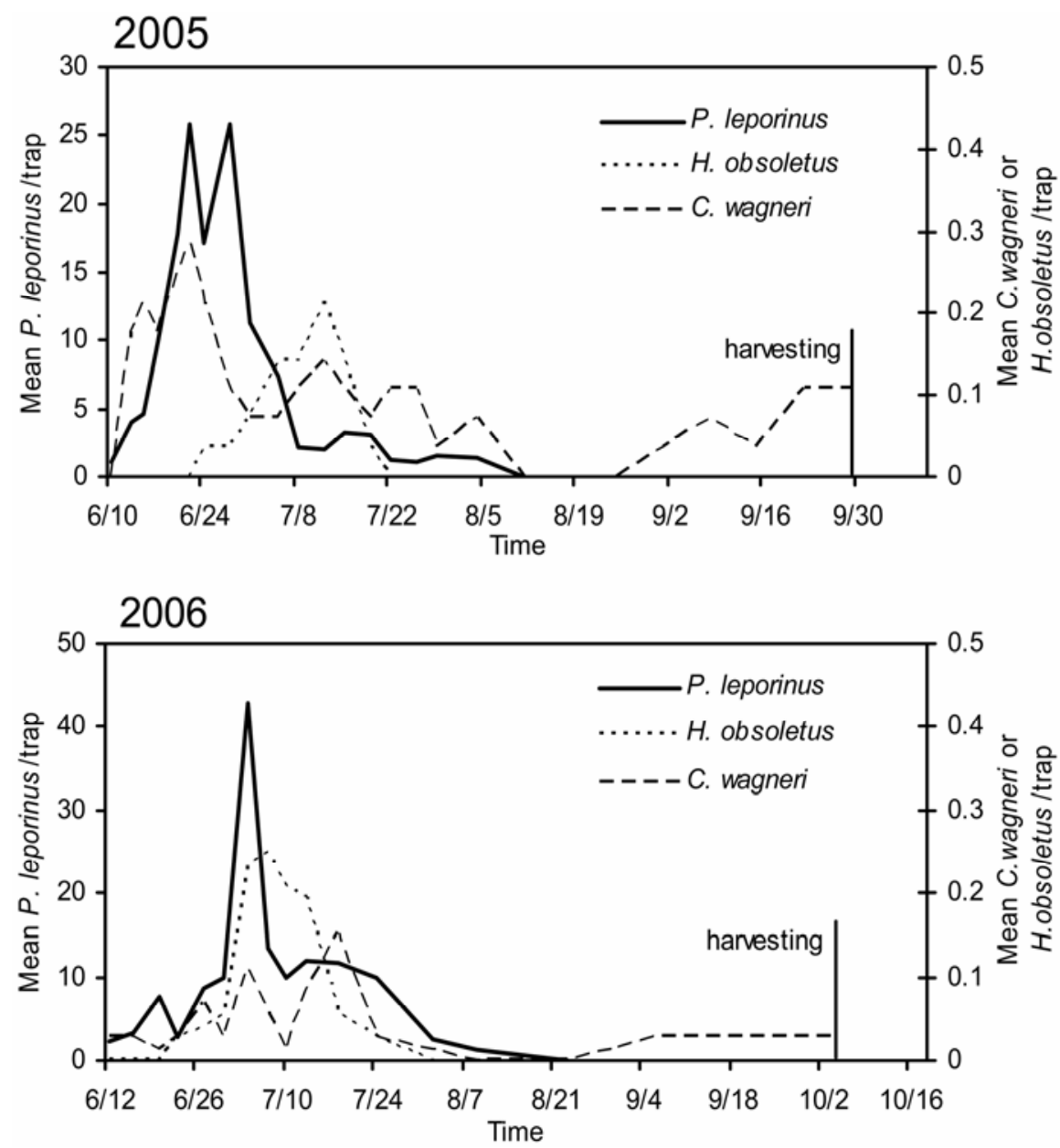

Fig. 1. Abundance (mean number caught per trap) and temporal distribution of three planthopper cixiids, Cixius wagneri, Hyalesthes obsoletus, and Pentastiridius leporinus, in sugar beet fields during 2005 and 2006. Insects were caught using transparent sticky traps. 
the Stol11 DNA fragment on DNA extracted from taproot or leaf midrib tissues.

Data for $C$. wagneri with regard to transmission and infection rates for both spring-summer- and autumn-collected populations of planthoppers are summarized in Figure $2 \mathrm{~A}$ and $\mathrm{B}$. When the results are partitioned, the spring-summer and autumn populations transmitted SBR bacterium to 8 of 15 and 4 of 10 exposed sugar beet plants, respectively. The frequency of SBR bacterial infection was (27/58) than in the spring-summer (9/25). Furthermore, spring-summer versus autumn proportions of both diseased plants and infected planthoppers were not statistically different when using a $\chi^{2}$ test $\left(\chi^{2}=\right.$ 0.43 , df $=1, P=0.51$; and $\chi^{2}=0.79$, $\mathrm{df}=$ $1, P=0.37$ for plants and insects, respectively).

Symptomatology of stolbur phytoplasma and SBR bacterium in sugar beet. Stolbur phytoplasma and SBR bacterium caused similar types of symptoms on sugar beet (Fig. 4). Stolbur phytoplasma, higher for insects collected in the autumn

however, induced more leaf proliferation than the SBR bacterium. There was a significant reduction $(F=6.39$, df $=2.33, P=$ 0.004) in the plant biomass infected by stolbur phytoplasma or by SBR bacterium when compared with healthy sugar beet (Fig. 5A); the reduction in biomass was similar between the two pathogens. The proportion of tap root biomass/total plant biomass was significantly lower $(F=9.63$, df $=2.33, P<0.001)$ in stolbur-affected sugar beet (Fig. 5B) than in SBR bacterium-infected sugar beet (Fig. 5B). Nevertheless, these proportion were not statistically different from healthy sugar beet (control) that had proportions of tap root biomass/total plant biomass between those observed for stolbur phytoplasma- and SBR bacterium-infected plants (Fig. 5B). Tap root sugar content, expressed in RDS, did not differ between plants infected with the two pathogens; however, the lower RDS values for diseased sugar beet compared with that of healthy sugar beet were highly significant $(F=13.8, \mathrm{df}=2.33, P<$ 0.001) (Fig. 5C).
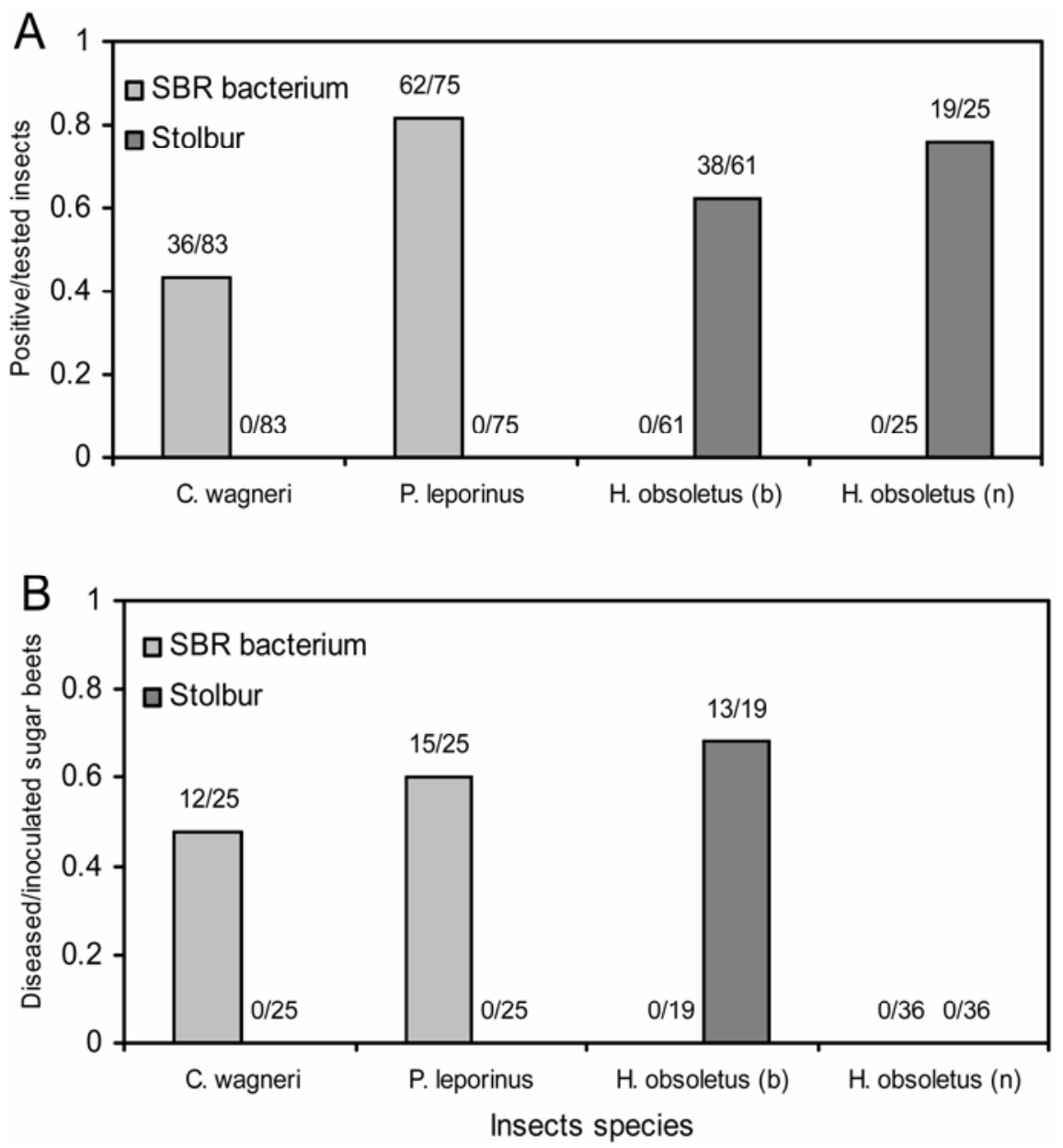

Fig. 2. A, Proportion of planthoppers infected by syndrome "basses richesses" (SBR) bacterium or stolbur phytoplasma. Specimens of Cixius wagneri and Pentastiridius leporinus were tested individually. Specimens of Hyalesthes obsoletus (b) and Hyalesthes obsoletus (n) were tested in batches of three. B, Proportion of diseased sugar beet seedlings infected by SBR bacterium or by stolbur phytoplasma after inoculation with field-collected $C$. wagneri, $H$. obsoletus, or P. leporinus. Individuals of H. obsoletus were collected either from bindweed (b) or from nettle (n). Protocols for detection of plant pathogens in seedlings and in insects are described in Material and Methods.

\section{DISCUSSION}

Our results clarified the role of planthoppers within the family Cixiidae as vectors of phloem-restricted plant pathogens belonging to either mollicutes (stolbur phytoplasma) or $\gamma-3$ proteobacteria (SBR bacterium) that cause SBR of sugar beet. Three planthopper species, C. wagneri, H. obsoletus, and P. leporinus, occurred in sugar beet fields; however, our results showed that each had a different role in spreading the two pathogens associated with SBR disease.

$P$. leporinus, which was referred to in previous literature as Pentastiridius sp. (10,23-25) and P. beieri (11), was the only known vector of both stolbur phytoplasma and SBR bacterium to sugar beet $(9,10)$. In this study, we found further evidence that P. leporinus is the economic vector of SBR disease in nature, because of its much greater relative abundance and higher frequency of infection with the SBR bacterium. Although unusually high for insect vectors, percentages of infection of $80 \%$ or even higher were noted in a previous study (23), and this explains why SBR bacterium, rather than stolbur phytoplasma, is the major pathogen of SBR disease in eastern France. This is the first time that planthopper $C$. wagneri was reported in sugar beet fields. C. wagneri is known as the economic vector of ' $\mathrm{Ca}$. Phlomobacter fragariae' to strawberry in western France (5). We could not detect ' $\mathrm{Ca}$. Phlomobacter fragariae' in field populations of $C$. wagneri collected from eastern France. We also showed that $C$. wagneri harbored and could transmit SBR bacterium to sugar beet, and this is the first evidence that SBR bacterium can be vectored by an insect species other than $P$. leporinus. Our results suggest that $C$. wagneri, because of its low numbers in nature, has a secondary role in spreading SBR to sugar beet. We found that adults of $C$. wagneri occurred in spring and in autumn, suggesting the possibility of two generations a year. Under our experimental conditions, insects captured in both spring and autumn were able to infect sugar beet with the SBR bacterium. We observed that $C$. wagneri was most abundant in patches of sugar beet fields infested by Polygonum spp., but we were unable to detect SBR bacterium in these plant species (unpublished data). We suggest that the vectoring activity of $C$. wagneri in sugar beet fields is a consequence of feeding on SBR bacteriuminfected sugar beet inoculated by $P$. leporinus during late spring and, thus, acquiring the pathogen. This may explain the higher frequency of detection of SBR bacterium in $C$. wagneri planthoppers collected in autumn than in those collected in spring.

H. obsoletus is known as a vector of stolbur phytoplasma to several plant species. Langer and Maixner (15) showed that populations of $H$. obsoletus living on bindweed or nettle carried distinct stolbur 
phytoplasma isolates. Furthermore, other researchers showed that these isolates occur widely in wild and cultivated plants in Europe $(1,20)$, and both are pathogenic on grapevines (15). In our comparison of the two isolates for pathogenicity on sugar beet, the nettle type of stolbur phytoplasma could not be detected in exposed sugar beet even though survival of planthoppers from nettle and bindweed during the transmission trials was comparable. Because we could not mechanically inoculate phytoplasmas directly to test plants, we used a very large number of insects per plant and confirmed that the vector population had a high frequency of stolbur phytoplasma infection; nevertheless, we could not detect successful transmission. Thus, our transmission data indicate that the phytoplasma type carried by $H$. obsoletus populations from nettle is not transmissible to or pathogenic on sugar beet, suggesting a different host range for these closely related phytoplasma isolates.

Stolbur phytoplasma and SBR bacterium cause similar symptoms in sugar beet, including reduced growth, chlorosis, proliferation and deformation of apical leaves, and necrosis of vascular tissues in tap roots. Nevertheless, in our experimental conditions, stolbur phytoplasma induced a stronger foliage proliferation than SBR bacterium and caused a heavier reduction of tap root biomass and sugar content. Because of its high pathogenicity to sugar beet, stolbur phytoplasma poses a potential threat to the sugar beet industry. Modification in environmental conditions or agronomical practices that lead to changes in the insect vector's host plant preference or to an increasing presence of weeds favorable for vector and phytoplasma populations may increase the rate of stolbur transmission and the final impact of stolbur phytoplasma-associated SBR disease in sugar beet. Finally, it is not known whether competition between stolbur phytoplasma and SBR bacterium may occur in either insect vectors or host plants. The ecological niches of these parasites overlap in host plants, both being restricted to the sieve tubes in phloem tissues (10), as well as in insect vectors, both requiring hemocoel colonization in order to be successfully transmitted. The high infection rates of SBR bacterium that have been reported here and elsewhere (23) in populations of P. leporinus during epidemics of SBR disease may have progressively excluded the presence of stolbur phytoplasma detected previously in $P$. leporinus populations $(9,11)$. Overall, our research strengthened the conclusions of other studies $(5,9,11$, $14,17,26)$ showing that planthopper vectors within the family Cixiidae play prominent and complex roles in epidemics of plant diseases associated with phloem-restricted bacteria and phytoplasmas in Europe.
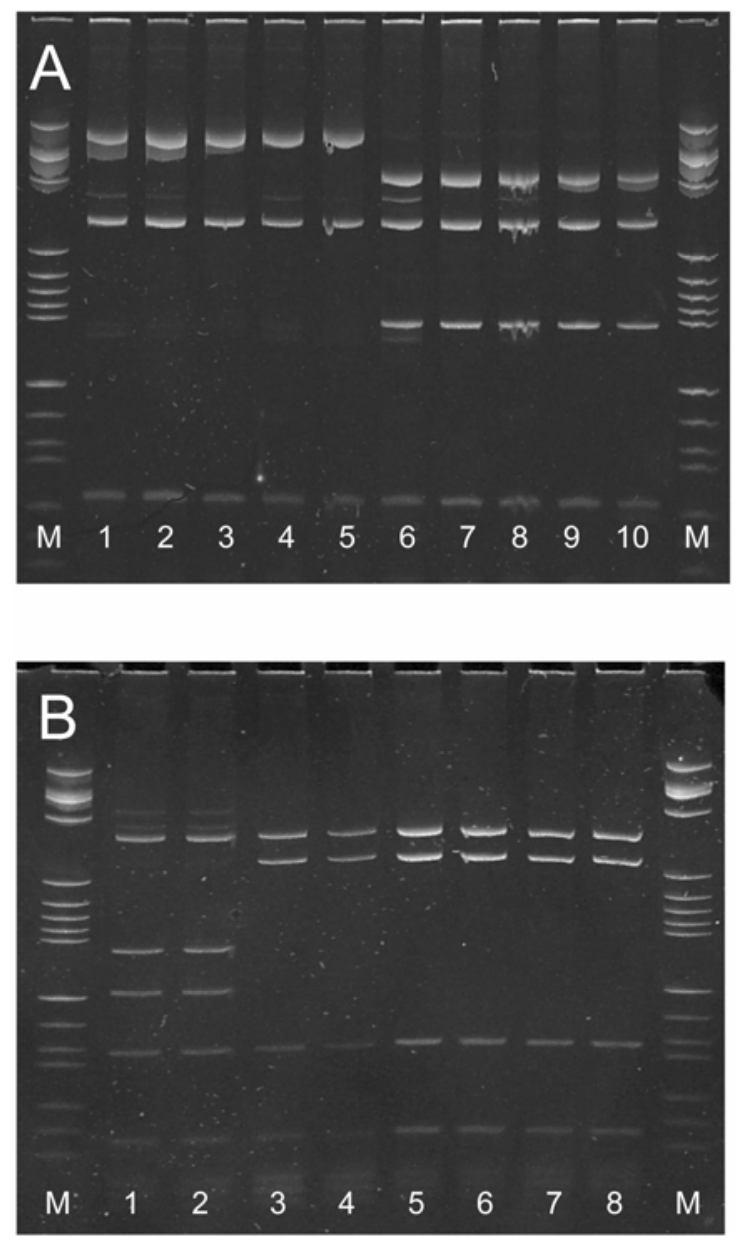

Fig. 3. Polyacrylamide gel electrophoresis of polymerase chain reaction-restriction fragment length polymorphism products. A, HpaII restricted ftufAY/rtufAY amplicons obtained with DNA samples from lanes 1-3, stolbur phytoplasma-infected Hyalesthes obsoletus specimens captured from bindweed; lanes 4-5, stolbur phytoplasma detected in sugar beet seedlings exposed to the latter $\mathrm{H}$. obsoletus bindweed specimens; lanes 6-10, stolbur phytoplasma-infected $H$. obsoletus specimens captured from nettle. M: HaeIII-digested pBR marker. B, TaqI-restricted Fra5/rA_PB_2 amplicons obtained with DNA samples from lanes 1-2, strawberry infected by "Candidatus Phlomobacter fragariae"; lanes 3-6, sugar beet seedlings exposed to Pentastiridius leporinus; lanes 7-8, sugar beet seedlings exposed to Cixius wagneri. M: HaeIII-digested pBR marker.

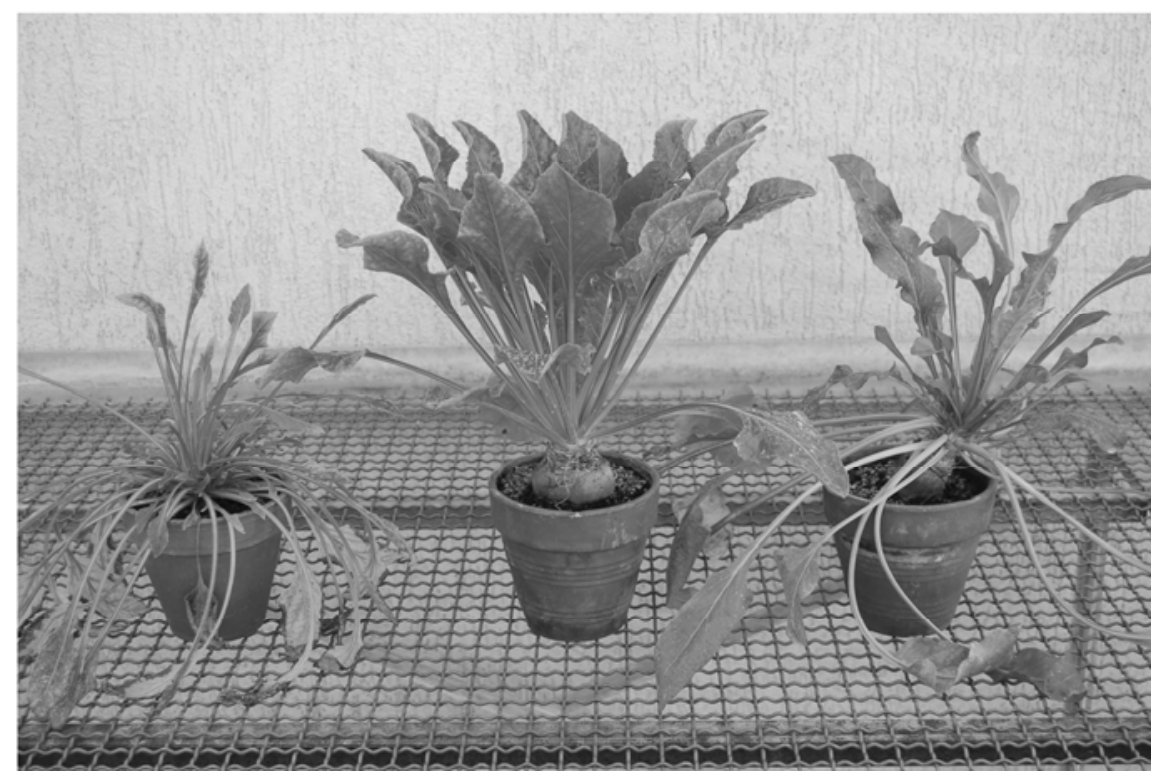

Fig. 4. Late-stage symptoms of sugar beet infected as seedlings by stolbur phytoplasma (left) or by syndrome "basses richesses" (SBR) bacterium (right) and healthy sugar beet (center). Note that stolbur phytoplasma-infected plants showed a stronger proliferation of leaves than those infected by SBR bacterium. Photo was taken 5 months after inoculation. 
A

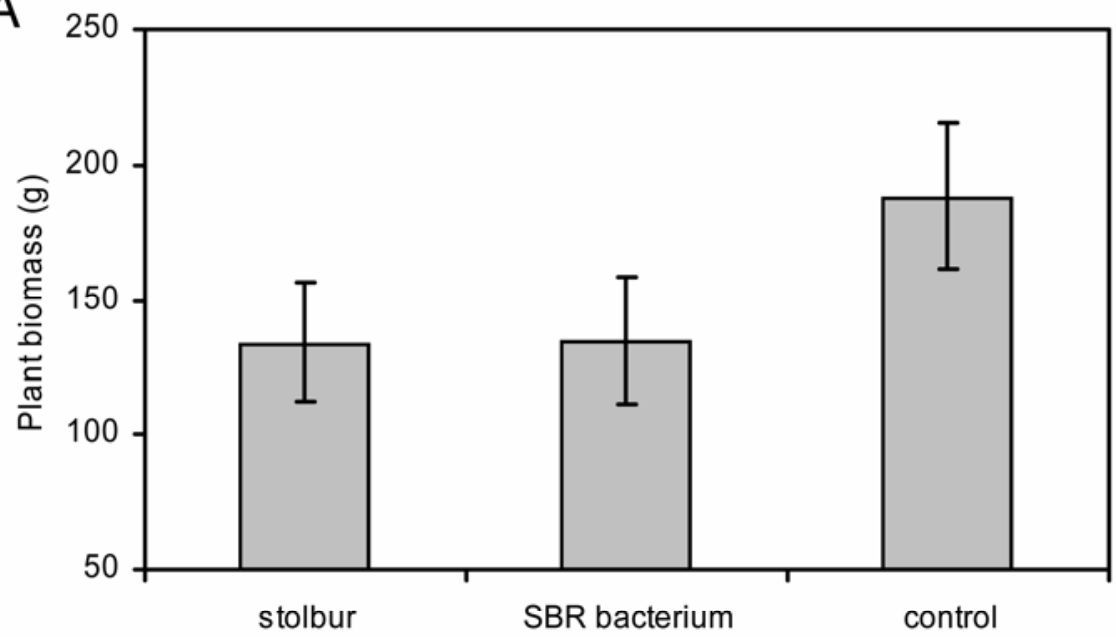

$\mathrm{B}$

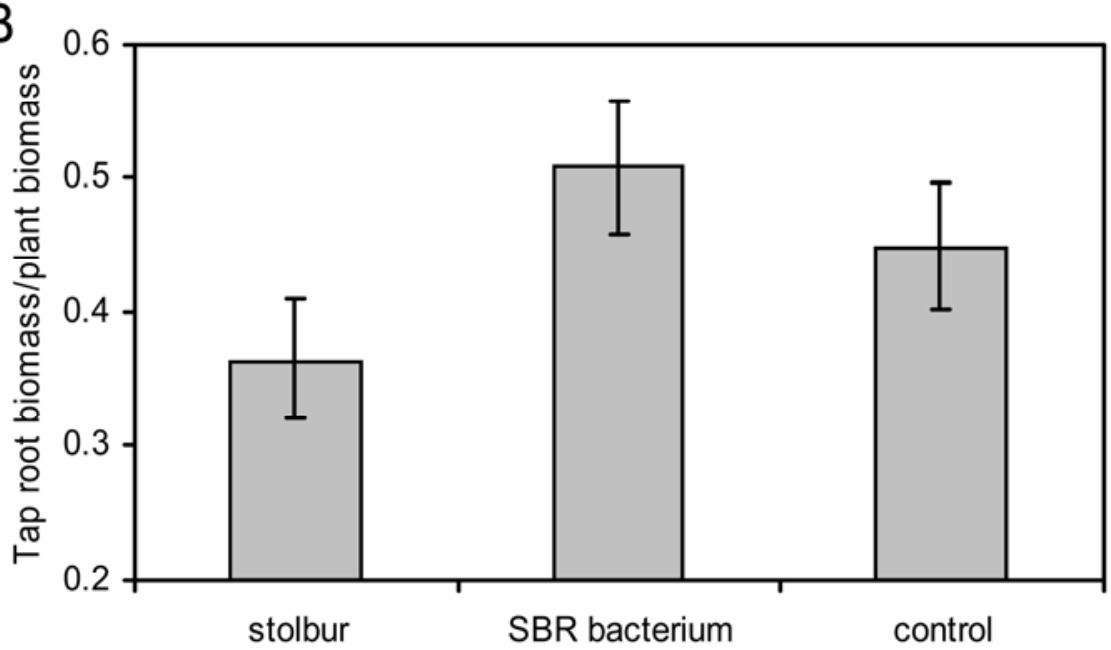

C

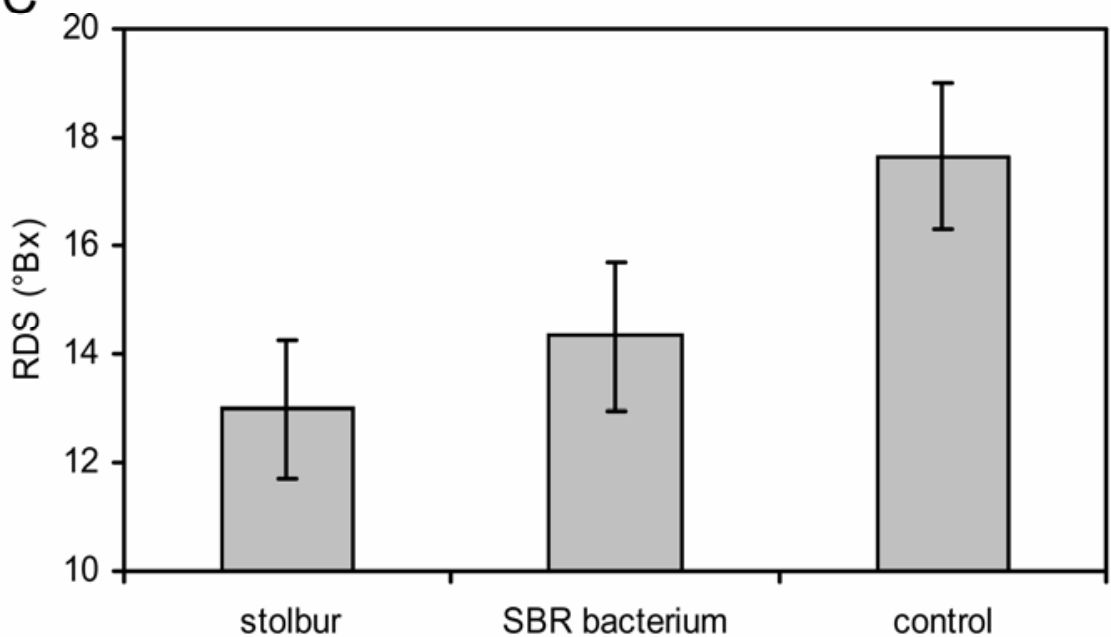

Fig. 5. A, Mean biomass of sugar beet infected as seedlings by stolbur phytoplasma, syndrome "basses richesses" (SBR) bacterium, or uninoculated sugar beet (control). B, Mean proportion of tap root biomass/total plants biomass infected by stolbur phytoplasma or SBR bacterium, or of healthy sugar beet (control). C, Mean Brix degree $\left({ }^{\circ} \mathrm{Bx}\right)$ of sugar beet tap roots infected by stolbur phytoplasma or SBR bacterium, or healthy sugar beet (control). Vertical bars represent $95 \%$ confidential limits. Stolbur phytoplasma were inoculated to sugar beet seedlings by Hyalesthes obsoletus collected from bindweed; SBR bacterium were inoculated by Pentastiridius leporinus.

\section{ACKNOWLEDGMENTS}

This work was supported by the Institut technique de la betterave industrielle (ITB) and the Conseil Régional de Bourgogne. We thank A. H. Purcell for comments and helpful suggestions on the manuscript.

\section{LITERATURE CITED}

1. Bertaccini, A., Paltrinieri, S., Botti, S., Duduk, B., Fiore, N., Kolber, M., Skoric, D., Torres, phytoplasmas detected in grapevine growing E., and Conti, M. 2006. Diversity of 16SrXII areas worldwide. Pages $88-89$ in: Proc. 15th ICVG Meeting, Stellenbosch, South Africa.

2. Bressan, A., Turata, R., Maixner, M., Spiazzi, S., Boudon-Padieu, E., and Girolami, V. 2007. Vector activity of Hyalesthes obsoletus living on nettle and transmitting a stolbur phytoplasma to grapevines. A case study. Ann. Appl. Biol. 150: 331-339.

3. Clair, D., Larrue, J., Aubert, G., Gillet, J. Cloquemin, G., and Boudon-Padieu, E. 2003. A multiplex nested-PCR assay for sensitive and simultaneous detection and direct identification of phytoplasma in the elm yellows group and stolbur group and its use in survey of grapevine yellows in France. Vitis 42:151157.

4. Daire, X., Clair, D., Reinert, W., and BoudonPadieu, E. 1997. Detection and differentiation of grapevine yellows phytoplasmas belonging to the elm yellows group and to the stolbur subgroup by PCR amplification of nonribosomal DNA. Eur. J. Plant Pathol. 103:507514.

5. Danet, J. L., Foissac, X., Zreik, L., Salar, P., Verdin, E., Nourrisseau, J. G., and Garnier, M. 2002. "Candidatus Phlomobacter fragariae" is the prevalent agent of marginal chlorosis of strawberry in French production fields and is transmitted by the planthopper Cixius wagneri (China). Phytopathology 93:644-649.

6. Firrao, G., Gibb, K., and Streten, C. 2005. Short taxonomic guide to the genus "Candidatus Phytoplasma." J. Plant Pathol. 87:249-263.

7. Foissac, X., Danet, J.-L., Zreik, L., Gandar, J., Nourrisseau, J.-G., Bové, J. M., and Garnier, M. 2000. Cloning of the spoT gene of "Candidatus Phlomobacter fragariae" and development of a PCR-restriction fragment length polymorphism assay for detection of the bacterium in insects. Appl. Environ. Microbiol. 66:3474-3480.

8. Fos, A., Danet, J. L., Zreik, L., Garnier, M., and Bové, J. M. 1992. Use of monoclonal antibody to detect the stolbur mycoplasma like organism in plants and insects and to identify a vector in France. Plant Dis. 76:1092-1096.

9. Gatineau, F. 2002. Rôle Etiologique du Phytoplasme du Stolbur et d'un Bacterium-Like Organism (BLO) dans le Syndrome des Basses Richesses (SBR) de la Betterave Sucrière (Beta vulgaris L.). Epidémiologie de la Maladie et Biologie du Vecteur Identifié, le Cixiide Pentastiridius beieri, Wagner. Ph.D. thesis, Université de Bourgogne, Dijon, France.

10. Gatineau, F., Jacob, N., Vautrin, S., Larrue, J., Lherminier, L., Richard-Molard, M., and Boudon-Padieu, E. 2001. Association with the syndrome "basses richesses" of sugar beet of a phytoplasma and a bacterium-like organism transmitted by a Pentastiridius sp. Phytopathology 92:384-392.

11. Gatineau, F., Larrue, J., Clair, D., Lorton, F., Richard-Molard, M., and Boudon-Padieu, E. 2001. A new natural planthopper vector of stolbur phytoplasma in the genus Pentastiridius (Hemiptera: Cixiidae). Eur. J. Plant Pathol. 107:263-271.

12. Holzinger, W. E., Kammerlander, I., and Nickel, H. 2003. The Auchenorrhyncha of Central Europe-Die Zikaden Mitteleuropas (Volume 1): Fulgoromorpha, Cicadomorpha excl. Cicadellidae. Brill Publishers, Leiden, Germany.

13. International Commission for Uniform Methods of Sugar Analysis. 2005. ICUMSA Methods Book 2005. Bartens the Sugar and Sweetener Publisher, Berlin, Germany.

14. Jovic, J., Cvrkovic, T., Mitrovic, M., Krnjajic, S., Redinbaugh, M. G., Pratt, R. C., Gingery, R. E., Hogenhout, S. A., and Tosevski, I. 2007. Roles of stolbur phytoplasma and Reptalus panzeri (Cixiinae, Auchenorrhyncha) in the epidemiology of maize redness in Serbia. Eur. J. Plant Pathol. 118:85-89. 
15. Langer, M., and Maixner, M. 2004. Molecular characterisation of grapevine yellows associated phytoplasmas of the stolbur-group based on RFLP-analysis of non-ribosomal DNA. Vitis $43: 191-199$.

16. Lee, I.-M., Gundersen-Rindal, D. E., Davis, R. E., and Bartoszyk, I. M. 1998. Revised classification scheme of phytoplasmas based on RFLP analyses of 16S rRNA and ribosomal protein gene sequences. Int. J. Syst. Bacteriol. 48:1153-1169.

17. Maixner, M. 1994. Transmission of German grapevine yellows (Vergilbungskrankheit) by the planthopper Hyalesthes obsoletus (Auchenorrhyncha: Cixiidae). Vitis 33:103104.

18. Minucci, C., and Boccardo, G. 1997. Genetic diversity in the stolbur phytoplasma group. Phytopathol. Mediterr. 36:45-49.

19. Palermo, S., Elekes, M., Botti, S., Ember, I., Alma, A., Orosz, A., Bertaccini, A., and Kolber, M. 2004. Presence of stolbur phytoplasma in Cixiidae in Hungarian vineyards. Vitis 43:201-203.
20. Pasquini, G., Ferretti, L., Albanese, G., Bagnoli, B., Pinzauti, F., and Barba, M. 2006. Geographical distribution of stolbur isolates in vineyards of Central and Southern Italy. In: Proc. 15th ICVG Meeting, Stellenbosch, South Africa.

21. Purcell, A. H. 1982. Insect vector relationships with procaryotic plant pathogens. Annu. Rev. Phytopathol. 20:397-417.

22. Schneider, B., Gibb, K. S., and Seemüller, E. 1997. Sequence and RFLP analysis of the elongation factor $T u$ gene used in differentiation and classification of phytoplasmas. Microbiology 143:3381-3389.

23. Sémétey, O., Bressan, A., Gatineau, F., and Boudon-Padieu, E. Development of a specific assay using RISA for detection of the bacterial agent of "basses richesses" syndrome of sugar beet and confirmation of Pentastiridius sp. (Fulgoromopha, Cixiidae) as the economic vector. Plant Pathol. 56:797-804.

24. Sémétey, O., Bressan, A., Richard-Molard, M., and Boudon-Padieu, E. 2007. Monitoring of proteobacteria and phytoplasma in sugar beet naturally or experimentally affected by the disease syndrome "basses richesses." Eur. J. Plant Pathol. 117:187-196.

25. Sémétey, O., Gatineau, F., Bressan, A., and Boudon-Padieu, E. 2007. Characterization of a $\gamma-3$ proteobacteria responsible for the syndrome "basses richesses" of sugar beet transmitted by Pentastiridius sp. (Hemiptera: Cixiidae). Phytopathology 97:72-78.

26. Trivellone, V., Pinzauti, F., and Bagnoli, B. 2006. Reptalus quinquecostatuts (Dufour) (Auchenorrhyncha: Cixiidae) as a possible vector of stolbur-phytoplasma in a vineyard in Tuscany. Redia 88:103-108.

27. Weintraub, P. G., and Beanland, L. 2006. Insect vectors of phytoplasmas. Annu. Rev. Entomol. 51:91-111.

28. Zreik, L., Bové, J. M., and Garnier, M. 1998. Phylogenetic characterization of the bacterium-like organism associated with marginal chlorosis of strawberry and proposition of Candidatus taxon for the organism, "Candidatus Phlomobacter fragariae." Int. J. Syst. Bacteriol. 48:257-261. 